\title{
Trees in Urban Ecosystem: Connection between New Urbanism, Society and Rational Risk Management ${ }^{1}$ El árbol en el ecosistema urbano: relaciones entre nuevo urbanismo, sociedad y gestión racional del riesgo²
}

doi:10.11144/Javeriana.iyu20-1.tuec

How to cite this article:

P. Calaza Martínez, "Trees in urban ecosystem: Connection between new urbanism, society and rational tisk management," Ing. Univ., vol. 20, no. 1, pp. 155-173, 2016. http://dx.doi.org/10.11144/Javeriana.iyu20-1.tuec

\footnotetext{
'This article is derived from a conference. Submitted on: June $11^{\text {th }}, 2013$. Accepted on: May $26^{\text {th }}, 2015$ This article is derived from a conference.

${ }^{2}$ Artículo de reflexión. Fecha de recepción: 11 de junio de 2013. Fecha de aceptación: 26 de mayo de 2015. Este artículo surge de una conferencia.

${ }^{3} \mathrm{BSC}$ in Agricultural Engineering, University of Santiago de Compostela, Spain. MSc in Agricultural Engineering, University of Santiago de Compostela. PhD Engineering, University of Santiago de Compostela. Dean of Official College of Agricultural Engineers of Galicia, La Coruña, Spain. E-mail: calaza@iies.es
} 


\section{Abstract}

The relentless and massive population migration process to the cities is a phenomenon of great concern due to the large urban overcrowding and the consequent environmental, public health, and social problems involved, among others. In fact, in this century, Pickett already talks of "urban species," where more than $50 \%$ of the world's population already lives in cities. Within the different theories, approaches, and strategies to carry out a more rational territorial development that generates healthy cities, greening processes, and green infrastructure, the need to try to mitigate these terrible consequences is highlighted. This strategy, recently endorsed by the EU, has numerous benefits and components such as green roofs, vertical gardening, greenways, etc., although perhaps one of the most important is the urban forest. Its governance is extremely important and should include, aside from the plans which maximize the benefits, those that minimize problems, and above everything the most important: its inherent potential danger. Sometimes trees have collapsed causing serious consequences, but often they are identifiable and preventable i.e. external biomechanics symptoms are indicators of internal problems. Therefore the incorporation of scientific and technical approaches (including specific tools such as tomograph, Static Load Test, etc.) about risk assessment should be an integral component of the management of green infrastructure.

\section{Keywords}

green Infrastructure; urban forestry; society; hazard risk assessment; biomechanics; management

\section{Resumen}

El incesante y masivo proceso migratorio poblacional hacia las grandes ciudades es un fenómeno de profunda preocupación debido a la gran masificación urbana y a los consecuentes problemas que genera, de tipo medioambiental, de salud pública, social, etc. De hecho, en este siglo ya se habla de especie urbana, donde más del $50 \%$ de la población mundial ya vive en las urbes. Para intentar mitigar estas terribles consecuencias y dentro de las diferentes teorías, planteamientos y estrategias para un desarrollo territorial más racional, que genere ciudades más sanas y saludables, destacan los procesos de naturación urbana y de infraestructura verde. Esta estrategia, avalada por la Unión Europea recientemente, tiene numerosos beneficios y componentes como tejados verdes, jardinería vertical, corredores verdes, pero quizás uno de los más importantes es el arbolado urbano. Su gestión racional es fundamental y debe incluir, aparte de los planes que optimicen los beneficios, aquellos que minimicen los problemas, sobre todo el más importante: su inherente peligrosidad potencial. A veces los árboles se colapsan y provocan graves consecuencias, pero muchas veces son identificables y prevenibles, ya que la sintomatología externa biomecánica es una gran indicadora de problemas internos. Por lo tanto, la incorporación de planteamientos científicos de evaluación de riesgo debe ser un componente integral de la gestión de la infraestructura verde.

\section{Palabras clave}

infraestructura verde; arbolado urbano; sociedad; evaluación de riesgo; biomecánica; gestión 


\section{Introduction}

This article tries to set out different reflections and goes in depth regarding different methodological approaches of the possibilities of a more natural territorial planning along the lines of the latest proposals of green infrastructure, analysing their varied components, and the benefits that they generate. A second part shows the special importance of urban trees in this kind of strategies and also tackles both the benefits and problems they produce, emphasizing the potential risk that they implicitly entail, which is one of the objectives that a rational and modern management must include.

To this end, first, it would be interesting to clarify two previous aspects that will be developed in different parts of this document in order to try to avoid bias in its conceptual approach. The first one is related to mathematics and how it has been studied and used like a means of job/study in addition to being essential tool in different disciplines related to engineering. We thoroughly agree with the remarks of the brilliant mathematics teacher from Edinburgh University, Michael Atiyah (1929), who affirms - and with good reason- that "mathematics are an universal language to study problems." However, being half science and half tool, when we immerse ourselves into the study of biological elements, such as the components of green infrastructure, a series of determinants of processes, variables, and parameters come into play, and while often controllable -with difficulty- they complicate to some extent, and at once enrich the situation. This is the case of the trees in the city and the different elements that are part of their management. The latter includes the potential risk, such as the applicability of formulas of loss of mechanical resistance of wood or certain approaches of some authors from the international outlook, deduced from the traditional physics, specifically from the solid mechanics.

Second, although the title of this article makes allusion to the relations between a possible new urbanism, trees, and society, it is necessary to remind the reader and bear in mind the inherent and dependent relations between territory, landscape, urbanism, society, and trees. All things considered, nowadays, the 
approaches and strategies of territorial planning tackle all these concepts and their interrelations, especially in the part of green infrastructure and trees, at the three levels: local, regional, and (inter)national.

\section{Urban Evolution. Territorial Planning and Green Infrastructure}

The first questions that should be asked are the following: What is the condition of cities in the world? What is the condition of the population that lives in those cities? What is the future?

In the 1800's there were only two cities with a million people: London and Beijing. Nowadays, over a hundred cities have more than 20 million inhabitants and accommodate 540 million people. In the United Nations Population Fund (UNFPA) report [1], Batatunde Osotimehin affirmed that as of October 31 there would be 7.000 million people and that in 13 years-time there would be 1.000 million more. He reflects on this and suggests that, instead of asking ourselves if we are too many people, perhaps we should ask ourselves iwhat can I do to make our world better? It is alarming that $50 \%$ of the world's population lives in cities since 2010, especially in the most developed regions, where numbers reach about $75 \%$. According to Forman [2], 5 billion people, about $60 \%$ of the world's population, will live in urban areas by 2030. In Western Europe, the percentage of population in large cities is about $80 \%$, emphasizing countries such as France (85\%), United Kingdom (80\%), Germany (74\%), and Spain $(77 \%)$.

According to UNPD data, the population in the cities grows rapidly, reaching 70 million people by year. In fact, this is an obvious worry and the result of international considerations. Steward T.A. Pickett, scientist from the Institute of Ecosystem Studies, already discussed this in the foreword of Forman's book [2] where he coined the phrase "first urban century;" the century in which humans have begun to be numerically an urban species.

This effect is easily visible in the urban evolution of cities like, Istanbul, Las Vegas (Figure 1), Santiago de Chile, among others. In particular, according to a study by Wessel [4], in Bogotá there were 711.520 inhabitants in 1950 and in the year 2000 there were almost 7 millions; the growth is amazing.

Everybody is aware that these are cities with high pollution levels, high population density where persons live rapidly, and time is important for the quality of life and the perception of the landscape. There are different researchers that analyse Timescaping, that is, the different perceptions of landscape depending of time. Sometimes, time is a key element in shaping the ephemeral landscapes, 
Figure 1. Urban evolution of Las Vegas (EEUU) form 1985 (top) to 2010 (bottom)
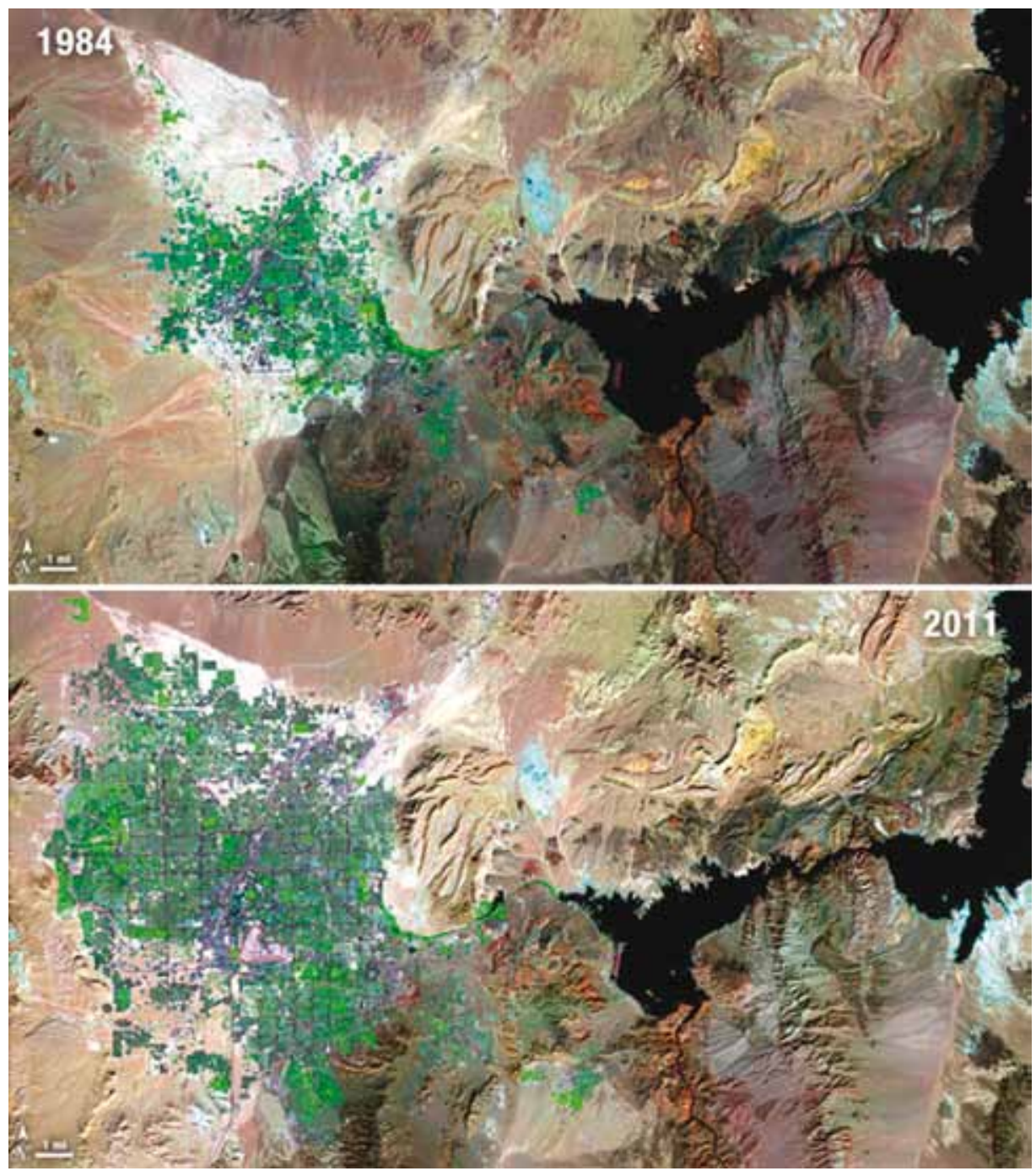

Source: [3].

like the famous tomato party, la Tomatina, in Buñol (Valencia), Spain; war episodes such as the Batalla de las Navas de Tolosa, or religious events like the Holy Week that invades the streets and changes the perception of urban scenarios. Even, sometimes violent natural events configure these ephemeral landscapes, for example when the crowns of trees were "decorated" with millions of spiders and their cobwebs during the last heavy rains in Pakistan. Coming back to the 
subject of time, people in big cities live quickly and that affects the quality of life, and that is where efforts must be made to improve welfare and quality of life.

In view of these circumstances, we must reflect on different concepts and about the future; about ecology, environment, quality of life, urbanism, nature, etc. This is, in an analogy to Charles Dickens "A Tale of Two Cities;" "a good city" which offers culture, work, and opportunities and "a bad city" which generates loss of contact with nature, health problems, among other issues. As the the famous writer and philosopher Thoureau said: "millions of people feeling lonely together."

Another important problem is the "urban heat island" effect which may be reduced by the use of vegetation in cities. Moreover, from a general point of view, diseases are changing and they are starting to be a global problem. For this reason new perspectives must be considered, such as the use of green areas to exercise, with the purpose of minimizing different stress impacts, respiratory diseases, cardiovascular risk, etc.

It is known that "fast urbanization" has caused natural environments to be by modern environments, generating great and serious repercussions in terms of public health and social welfare. These problems are made worse in cities with high population density and few public green areas, but there is an opportunity in our need of feeling nature. We are aware that nowadays, the first physical contact of many children with nature is in cities, and we ought to take advantage of that fact. This advantage allows us to introduce the term biophilia, coined by Wilson [5], meaning "the human bond with other species," that inherent predilection of man for nature; the deep affiliations humans have with nature are rooted in our biology. We have to take advantage of this feeling to integrate strategies, mechanisms, and natural elements into territorial planning, combining biophilia, green planning, and public health to achieve healthier cities. In Europe, there are interesting examples like London, Brondy, Paris, or Bath (World Heritage site and green planning paradigm) that work along these lines. Specifically, in Spain, there are good examples but many of them are of poor quality too; for this reason we have a great deal of hard work ahead of us. However, nowadays, engineers, architects, urban designers, and landscape architects reflect on the relations between ecology, urbanism, society, landscape, and sustainability and they are starting to hybridize concepts and to synergically develop interesting lines of work. In Spain, for example, most of their latest territorial development projects are carried out by means of multidisciplinary work teams where these kinds of strategies are combined. 
In any case, this is not a new topic; there are many authors that have worked in this field for centuries, indeed. Prominent among their number, we can find:

Frederik Law Olmsted, one of the first to work with concepts related to green infrastructure and how it provides benefits to population; significant examples of his work are Central Park and Boston's Emerald Necklace. Moreover, he is regarded as the father of landscape architecture.

The British architect and critic Cedric Price in his famous metaphor "the city like eggs," defined the city of the XXI century like a scrambled eggs dish, where urban and natural tissues get mixed up, hybridize, and coexist, looking for a perfect harmony (Figure 2). This metaphor continues to be very used, as Schenk from Next Architects explained in the discourse that he offered in the Groeningen Architect Academy [6].

Figure 2. "Three eggs diagram" by Cedric Price

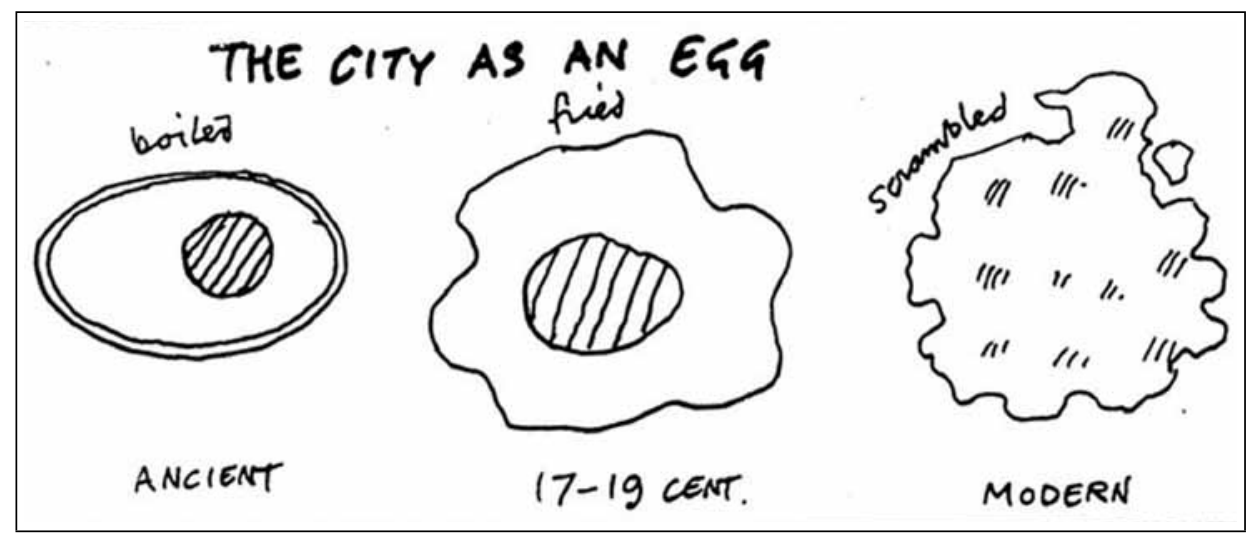

Source: [7, Fig. 1].

In this way, it is suggested that landscape may be the model to the third urban form. Logical development for the first form emerged in the agrarian Neolithic, which contains a central urban nucleus and its protected surroundings. For the second urban form the development rose at the time of the Industrial Revolution, which allowed the city extension, breaking the perimeter limit, the initial closure. This third form is more organic, in the words of Shane [7] "opener, decentralized, auto-organized, and with a pattern of postmodern matrix." In short, the aim is to promote green spaces like city natural theatres. This conceptual approach agrees with the Landscape Urbanism movement [8], and with the proposals of James Corner, who used a very clear word game that 
connects directly with Cedric Price's suggestions: "The city in the landscape and the landscape in the city" [9].

The second well-known person is Ian McHarg, landscape architect of Scottish origin, who is very interesting because of three aspects: firstly, being the father of Landscape Ecology; secondly, because he is the precursor of modern geographical information systems; and lastly, he is the author of the famous book "Design in Nature" [10] which stabilized the basis of a territorial planning more integrated with landscape, and paved the way that many other specialists would follow in this field.

These authors offer reflections, philosophy, methods, and proposals that must be used, considering that modern society needs a solution. It is known, also, that every day green infrastructure garners more importance, but, what exactly does this concept mean? For many people it means everything that is not grey infrastructure, i.e., roads, electrical installations, different kinds of infrastructures, etc. It could be said that it is similar to the positive and negative in a photograph, the grey and the green. There are numerous definitions at the international level, although surely Benedict and McMahon [11] offered one of the most complete: "An interconnected network of green space and other environmental assets that conserve the functions of the natural ecosystem and provide associated benefits to people."

The Union European have just published (May 6, 2013) the European green infrastructure strategy [12] and defines it as "...a successfully tested tool for providing ecological, economic and social benefits through natural solutions. It helps us to understand the value of the benefits that nature provides to human society and to mobilise investments to sustain and enhance them."

And it insists on the fact that "green Infrastructure is based on the principle that protecting and enhancing nature and natural processes, and the many benefits human society gets from nature, are consciously integrated into spatial planning and territorial development. Compared to single-purpose, grey infrastructure, GI has many benefits."

Also, it underlines the importance of the integration of these approaches in great cities, where more than $60 \%$ of the EU population lives:

GI features in cities deliver health-related benefits such as clean air and better water quality. Healthy ecosystems also reduce the spread of vector-borne diseases. Implementing Green Infrastructure features in urban areas creates a greater sense of community, strengthens the link with voluntary actions undertaken by civil society, and helps combat social exclusion and isolation. They benefit the individual and the community physically, psychologically, emotionally and 
socio-economically. GI creates opportunities to connect urban and rural areas and provides appealing places to live and work in.

This proposal of integrating nature into city, keeping in mind certain kind of benefits is not new either. There are many historic examples in the international framework like the Haarlem Forest in Holland, the approaches of Johan Henrich von Thunen, Ebenezer Howard's Garden City, the Le Corbusier's approaches between sun, green, and space, among many others. The incorporation of trees aligned to architectonical and recreational functioning; one of the first designed in Spain is located at Ferrol, although unfortunately, nowadays it is in terrible conditions.

All the previously mentioned signs of the condition of cities show the importance of the search for solutions and mechanisms to guarantee the population ways of life in cities and great cities. Solutions which are on the right track of sustainability, quality, health, economy, and environment, both for new urban growth and for applications that produce a city-shrinking effect, as identified and diagnosed in cities like Leipzig, Detroit, Ivanovo, Manchester, Liverpool, or Hague (Figure 3).

Figure 3. Recovery of an old military battery into a public park as a hub for the development of Green infrastructure (La Coruña, Galicia, España)

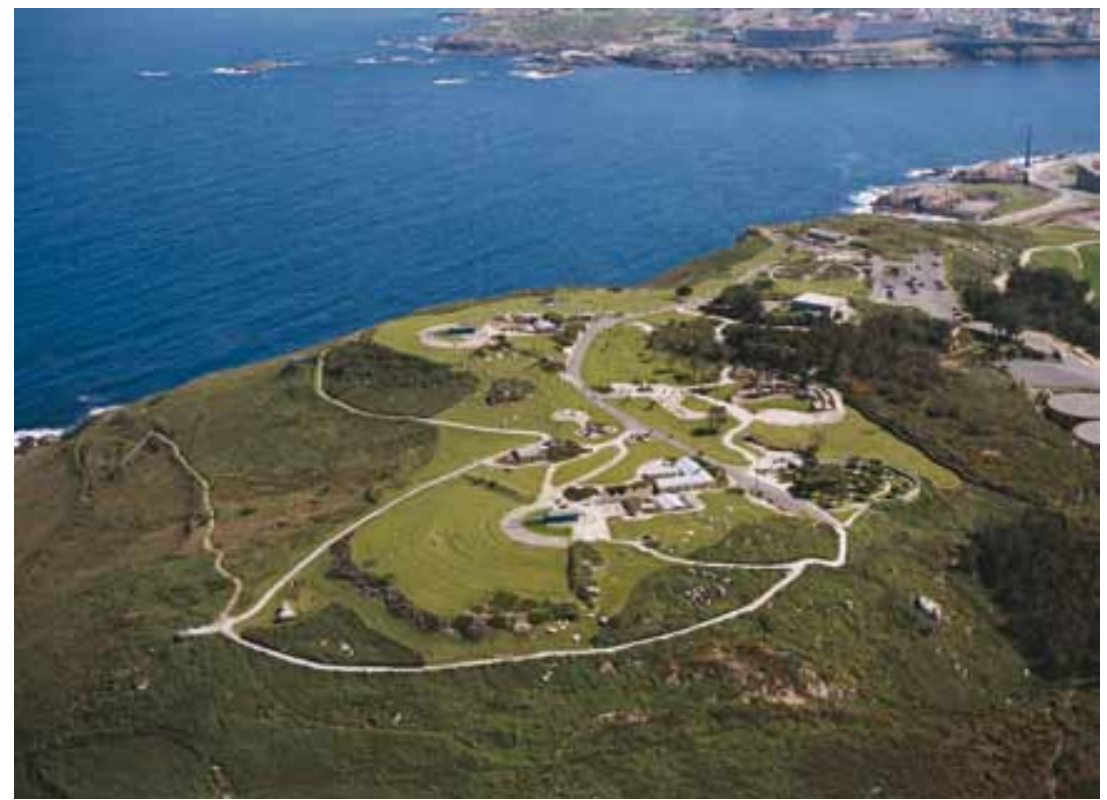

Source: Council of La Coruña. Environment Area, 2003. 
Another of the most important points to underline, and which should be kept in mind and taken into account during studies, is the direct benefits on public health. It is known that primary prevention presents the best results and is the cheapest within health improvement mechanisms. It is known that there are different studies which relate size, quality, or position of green spaces to quality of life or public health [13], [14]. In Europe, it is recommended that each citizen should have a green area greater than 5000 square meters at less than 300 meters from its home to guarantee the accessibility and the possibility of doing exercise during 30 minutes every day [15]-[17]. To study the applicability of these recommendations, the use of GIS analysis is a good option. In the Figure 4 a synoptic diagram of these recommendations is shown.

Figure 4. European recommendations for the accessibility to green spaces

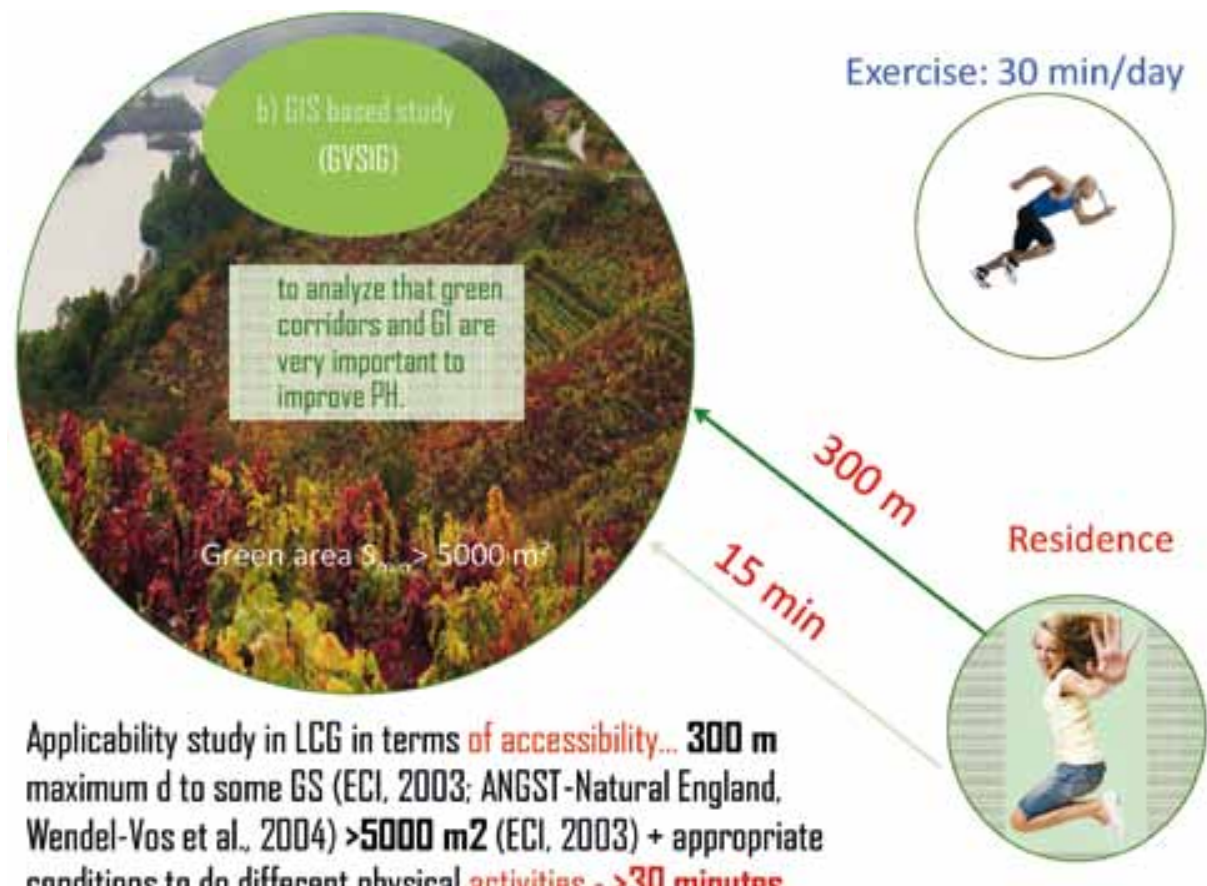
conditions to do different physical activities - >30 minutes.

Source: authors' own elaboration

Efforts must be made to ensure that the approaches coexist and hybridization exists between them. Also to ensure urban acupuncture processes happen in very populated areas so that natural systems mingle with anthropic systems in the never-ending search of sustainability. All of this in the search for urban 
greening with the incorporation and integration into cities of natural landscapes as an element of (green) infrastructure, an ecosystemic services generator.

Another aspect which must be taken into account related to urban pathology is the case of the new growths and transformations of our cities, because it is necessary to avoid the urbanalización (Spanish play on words: urbanize + trivialize, coined by Francesc Muñoz [18]) in the creation processes of monocultural urban landscapes, losing in this way the characteristic heritage of each particular place. We are liable to develop process proposals that include obvious bonds with the history and culture of the place, achieving attractive and dynamic places that citizens feel part of.

\section{Urban Forestry in Green Infrastructure}

Once that the problem and the different alternatives at the territorial planning level have been drawn, we are aware that we must emphasize on urban forest, out of the many components of green infrastructure, and on the benefits it produces, which have been studied in depth by different authors, such as Tzoulas et al. [19]. This is a fact supported by numerous articles and research projects developed in many countries. In Spain, for example, a report made by the Victoria Council shows the importance that these elements and trees alignments have in the production and intensity of different types of ecosystemic benefits.

It is known that urban forests are one of the most important elements and it is a large configurator of urban landscapes. For this reason they must looked after and managed in a rational way, although sometimes this practice is not properly understood or managed. The science that regulates these elements, urban arboriculture, is defined by Helms [20] like: "The art, science, and technology of managing trees and forest resources in and around urban community ecosystems for the physiological, sociological, economic, and aesthetic benefits trees provide society."

Moreover, it presents very well-defined characteristics: interdisciplinary, participative, urban, etc. In Europe it is a science sparking new interest; concretely it is not until the 90s when this worry becomes stronger thanks to great specialists like Konijnendijk, Randrup, and Nilsson [21]. From that moment onwards, with the editing of several reviews like Urban Forestry and Urban Greening, different reference books like Urban Forest and Trees, or the development of the COST E-12 project, it received the importance it deserves.

Also, it is true that different studies developed by entities such as CABE showed the regrettable condition of trees in Europe. A worrying loss of great 
size and old age specimens has been detected, in fact, for example, in the UK, only $11 \%$ of urban trees have between 50 and 100 years, and only $2 \%$ exceed that figure. Furthermore, we must bear in mind that urban trees have to start being considered as a responsibility by urban foresters and the general public. The last studies appeal to a rational management strategy as the point of departure towards a modern planning of the cities.

\subsection{Benefits and Drawbacks}

Everybody knows that trees generate important ecosystemic benefits of different nature. We only need analyse the significant work of researchers such as Gregory McPherson, David Nowak, or Francisco Escobedo, and delve into other kind of benefits like, among others, mitigation of the heat island effect, improvement of biodiversity, health and welfare, cultural heritage, improvement of the character of the city, urban hydrology, etc. Theodore Roosevelt stated: "To exist as a nation, to prosper as a state, and to live as people, we must have trees," and Claus Mattheck, author of one of the most used methods in urban tree risk assessment (Visual tree assessment) [22]-\{23] noted: "we can live between trees, under trees or over trees..."

Aside from problems mechanical in nature (interferences of the root system development, root reappearances, presence of thorns), problems related to people's health (toxic substances, allergies, etc.), and problems that cause interferences with the environment (species that impoverish ground, disagreeable smells, fruits that stain the road surface, etc.), the greatest problem is the inherent risk of causing material damages to personal goods or even leading to tragedy, causing a fatality. Sometimes, these risks cannot be controlled, for example when they derive from strong wind events or storms, but sometimes they are identifiable, predictable, and may be prevented.

\subsection{Tree Risk Management}

As we mentioned, those trees must be managed; to this end we should bring to mind the management objective that is offered by Dr. Andrew Kenny et al. [24]: "To optimize the leaf area of the entire urban forest by establishing and maintaining a canopy of genetically appropriate (adapted \& diverse) trees and shrubs with minimum risk to the public and in a cost-effective manner."

This definition is very clear and precise, and includes a part on risk management (greatest problem of urban trees). However, new perspectives and tendencies in this topic are changing with the purpose of enriching and making tree 
management more accurate, thus, a series of aspects are proposed, some adapted from the research project of Calaza and Quintanilla [25]:

a. To know and to emphasize the importance of the tree heritage.

b. To watch over the biodiversity improvement and to restrict the monoculture tree plantations based on the Santamour rule [26].

c. To improve city green planning.

d. To include green scene as an integral part of the infrastructure and to optimize the design of spaces and global planning, in accordance with the General Plan guidelines.

e. To optimize the environmental benefits of the green mass and the risk management of protected centenary or singular urban trees.

f. To look after and to protect vegetal health.

g. To manage plagues and diseases.

h. To inspect, to study and to analyse the problems of physiologic nature that appeared with the goal of optimizing the adaptation of specimens in specific positions.

i. To look after and to protect from a biomechanical and risk management point of view urban trees to guarantee the security. To include the general principles of a tree effective program set out by Schwab [27].

Risk management is part of numerous strategic plans for urban forest management [28]. In fact, this is the rational way to work that must be carried out like in Paris, Florence, Madrid, La Coruña, among others.

It is important to be aware of what dangers a tree poses, there are two important definitions:

- Matheny and Clark [29]: a tree is dangerous when the failure of one or more of its parts result in damages to properties and/or persons.

- Albers et al. [30] define a "dangerous tree" as a tree with structural defects that may provoke failures to both the whole tree and some of its parts and it could beat a "target."

The origins of risk assessment are old. Already in 1915, Peets offered a tool in his work "Tree repair," followed by Le Sueur with his work "The care and repair of ornamental trees." Then the works of Willis Wagener [31] who suggested one of the first formulas extracted from solid mechanics for the measurement of mechanical resistance of wood. Since 1991, when the first specific work about urban trees appears, many projects and studies are developed in different 
countries. Currently, there are very interesting methods and scientific studies. We emphasize on authors like Sinn and Wessolly, Horacek, Spatz, Mattheck, Matheny and Clark, Rinn, Francis Schwartze, etc.

In Spain, in particular, and in other Spanish-speaking countries, in general, the situation is less developed and there are few works. We can highlight the book Evaluación de riesgo de arbolado peligroso: principios, indicadores y métodos [32], where the state of the art at international level and different methods and indicators are detailed (Figure 5).

\section{Figure 5. Tree of disciplines related to tree hazard assessment}

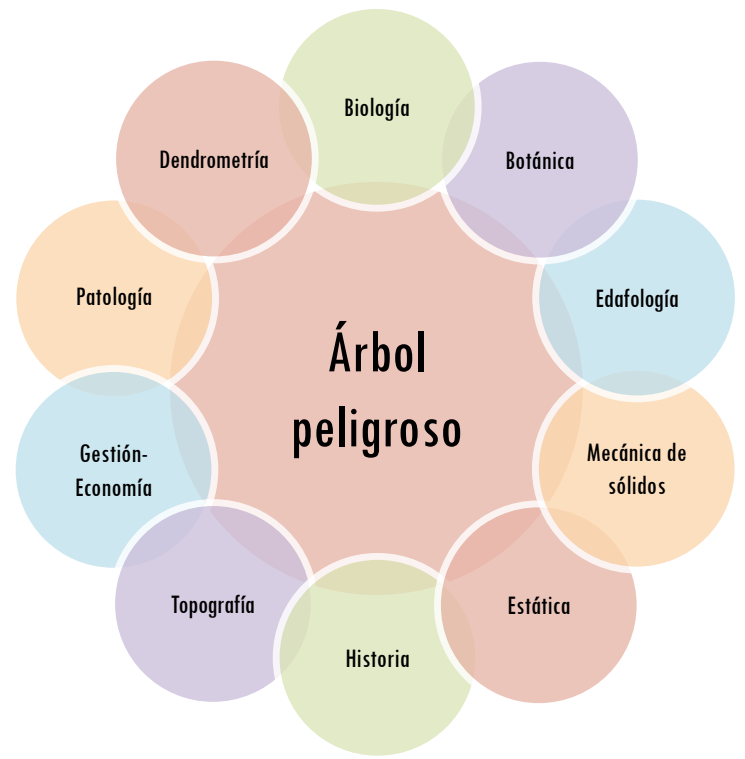

Source: authors' own elaboration

Risk assessment is a complicated technique derived from different topics; for that reason it is very important to bear in mind that technical training in different related disciplines is hugely important.

It is fundamental to interrelate all the parts that must be analysed, studying each case in detail and avoiding generalities. Examples must be analysed integrating the knowledge from the molecular level (cellulose percentages, lignin, type of fibres, etc.), and progressively increasing the scale (kind of wood, porosity, density, modulus of elasticity, etc.) until the last level, studying the whole specimen, researching what kind of symptoms, fungal decay, biomechanical alterations, cellulose and lignin degradation may be pesent, among 
other issues. In the Figure 6, a cloud is shown formed by different concepts, elements, tools, and disciplines that are closely linked with the process of tree hazard evaluation.

Figure 6. Cloud of concepts and diagnosis tools in tree hazard assessment.

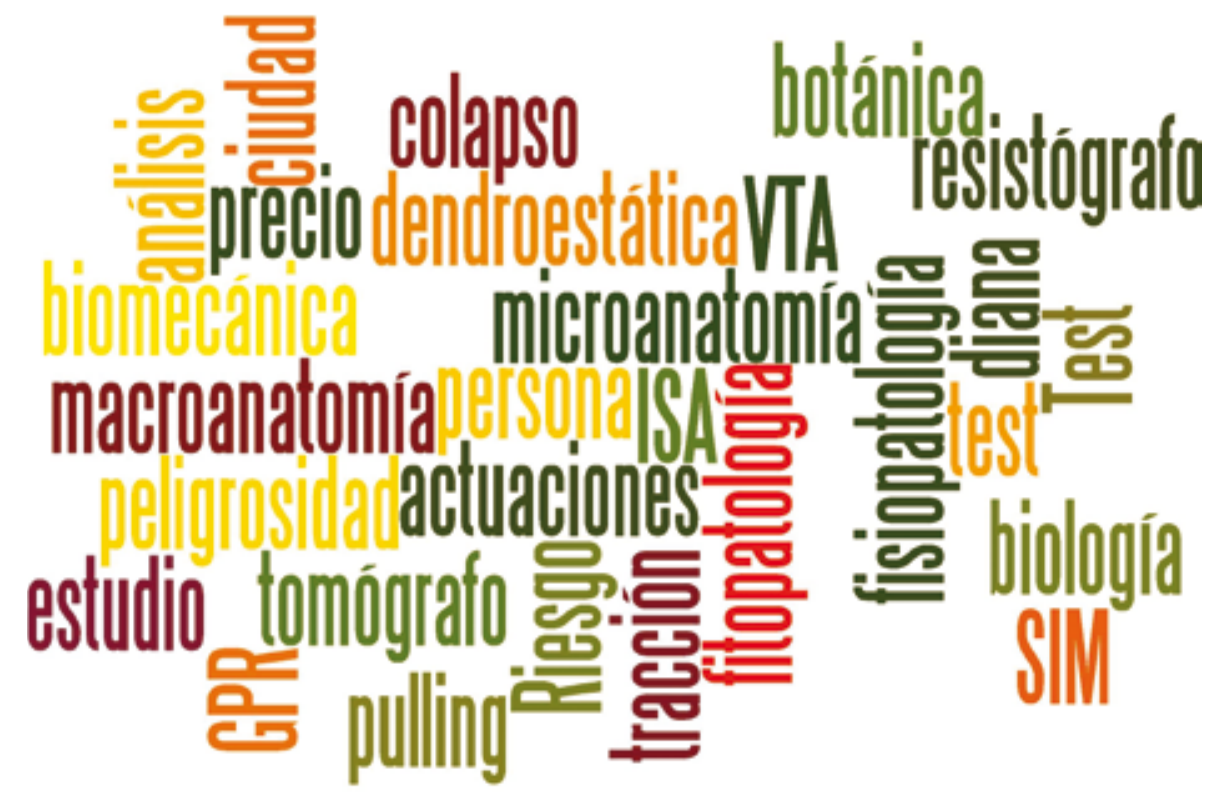

Source: authors' own elaboration

As mentioned at the beginning of this article, there are different formulas to measure the loss of mechanical resistance of wood, but the fixed rules, mathematics and exact sciences do not regulate this effect. For this reason they must be used as a complement and not as the final tool for calculation (Table 1).

For approximately 20 years many tree diagnostic tools have appeared on the market; however, we must be cautious because they are not the generic solution to the varied casuistry that can be found. Nowadays there is no tool that covers the different failure typologies and, besides, the precision is relative and depends in large part to research skills. Moreover, most of them need the use of another complementary tool to obtain more exact diagnoses and the most important thing is to know tree biology, anatomy, solid mechanics, etc. 
Table 1. Mathematical formulae to calculate loss of mechanical resistance of wood in living trees

\begin{tabular}{|l|l|l|l|}
\hline \multicolumn{1}{|c|}{ Source } & \multicolumn{1}{|c|}{ Formulae } & \multicolumn{1}{c|}{ Threshold } & \multicolumn{1}{c|}{ Comments } \\
\hline Wagener, 1963 & \multicolumn{1}{|c|}{$\left(\mathrm{d}^{3} / \mathrm{D}^{3}\right) \times 100$} & $33 \%$ & $\begin{array}{l}\text { Adjusted formula to account for } \\
\text { discontinuities in trunks. Applied only to } \\
\text { conifers without aggravating defects. }\end{array}$ \\
\hline Coder ,1989 & $\left(\mathrm{d}^{4} / \mathrm{D}^{4}\right) \times 100$ & $\begin{array}{l}20<\mathrm{x}<44 \% \\
\text { Precaution } \\
\mathrm{x}>50 \% \\
\text { Danger }\end{array}$ & $\begin{array}{l}\text { Based on engineering formula for bending } \\
\text { stress in a cylinder. Threshold based in } \\
\text { experience. }\end{array}$ \\
\hline $\begin{array}{l}\text { Smiley \& } \\
\text { Fraedrich, 1992 }\end{array}$ & $\begin{array}{l}\left(\mathrm{d}^{3}+\mathrm{r}\left(\mathrm{D}^{3}-\mathrm{d}^{3}\right)\right) / \\
\mathrm{D}^{3} \mathrm{x} 100\end{array}$ & $33 \%$ & $\begin{array}{l}\text { Modification of Wagener account for cavity } \\
\text { openings. Using 33\% strength loss as a } \\
\text { threshold for action. }\end{array}$ \\
\hline $\begin{array}{l}\text { Mattheck, } \\
\text { Gerhardt \& } \\
\text { Breloer, 1992 }\end{array}$ & $\mathrm{t} / \mathrm{R}$ & $\begin{array}{l}\text { Based on buckling failure in cylinders. } \\
\text { Measured } \mathrm{t} / \mathrm{r} \text { for fallen and standing trees. } \\
\text { Using a t/r }<0.3 \text { as a threshold for action. }\end{array}$ \\
\hline
\end{tabular}

Source: Adapted from Harris et al. (2004).

At the moment, there is a great number of tools with more or less precision, invasiveness, and different physical basis of work (penetration resistance, thermal images, electrical impedance, etc.) and some new others such as electronic nose [34]. We have to know how to choose depending on tree typology, urban typology, or on the problems that arise with specimen management. The basic concepts should not be forgotten and it is necessary to know the limitations of tools.

Inside the group of options, methods and tools, the SIM method, although is expensive enough, lets us calculate the risk of tipping, based on theories of applied dendrostatic. It is very useful when specimens of high cultural, inherited, or singular value are assessed. Theoretically, this method also allows the estimation of the risk of stem fracture.

More than two hundred years ago, Humpry Repton [35] affirmed the following: "the man of science and of taste will... discover the beauties which the others would condemn for decay," these days this quote has the same validity and quality.

\section{Perspective, Conclusions, and Opportunities}

Once data has been analysed, approaches, movements, and different reflections introduced in this text will be decided upon. The conclusions of different research works, for example Calaza and Quintanilla [25] who analysed more than 2400 trees from a biomechanical and instrumental point of view, following the $\mathrm{bf}^{2}$ protocol [32], could be as follows: 
a. Necessity of incorporating arguments of naturalistic kind, such as urban ecology, 'reurbanism', common scenario, etc., in modern cities.

b. Green infrastructure, in general terms and trees, in particular, represent a solution to current problems applied at different scales, in different contexts, and for different functions.

c. It is important to study in depth the conceptual framework and to apply the ideas of green infrastructure coherently. Changing reality into utopia by means of a strategic planning of high quality green networks.

d. Promotion of ecosystemic services. Economy-argument.

e. It is necessary to work in multidisciplinary work groups and to integrate the preservation and maintenance from the initial phases in a coherent and technical way.

Related to integral risk management:

a. The need to improve the knowledge on the processes of risk evaluation in different urban situations and typologies.

b. The need to incorporate risk management into the integral management of urban trees, from a scientific perspective.

c. The need to improve the technical training of arboriculture professionals. Tools are not the only answer.

d. Science must be the point of departure to develop handbooks and manuals for the selection of species, including parameters from a mechanical point of view (risk maps, species resistant to windy areas, etc.)

e. Nowadays, there are not precise diagnosis tools that allow the identification of all the mechanical problems, mainly those related to the root plate stability. It is necessary the use of tools in a combined way.

\section{References}

[1] United Nations Population Fund (UNFPA), "Estado de la población mundial: desde conflictos con crisis hacia la renovación: generaciones de cambio." Washington: Organización de las Naciones Unidas, 2011.

[2] R.T.T. Forman, Urban Regions Ecology and Planning beyond the City. Cambridge, UK: Cambridge University Press, 2010.

[3] B. Mason. 40 Years of Massive City Growth as Seen from Space. Wired: Conde Nast. [Online]. Available: http://www.wired.com/wiredscience/2012/07/landsat-city-change.

[4] G. Wessels, C. F. Pardo, and J. P. Bocarejo. "Bogotá 21 - towards a world-class, TransitOriented Metropolis, Bogotá.” 2012 [Online]. Available: http://www.eltis.org/docs/tools/ Bogota-21-Espanol.pdf. 
[5] E. O. Wilson, Biofilia: The Human Bond with Other Species. Boston: Harvard University Press, 1984.

[6] S. Hooijer. "NEXT architects: Searching to balance city and countryside." [Online]. Available: http://www.archined.nl/en/news/2011/engels/next-architects-searching-tobalance-city-and-countryside/.

[7] G. Shane, "The Emergence of Landscape Urbanism," in The Landscape Urbanism Reader, ed. Charles Waldheim. New York: Princeton Architectural Press, 2006.

[8] C. Waldheim, "Introduction: A Reference Manifesto," in The Landscape Urbanism Reader, ed. Charles Waldheim. New York: Princeton Architectural Press, 2006.

[9] J. Corner, "Terra Fluxus," in Landscape Urbanism Reader, Ed. Charles Waldheim. New York: Princeton Architectural Press, 2006.

[10] I. Mcharg, Design with Nature. Washington: Wiley, 1969.

[11] E. Benedict and B. McMahon, Green Infrastructure: Linking Landscapes and Communities. Washington, Covelo, USA: Island Press, 2006.

[12] European Union, "Communication from the Commission to the European Parliament, the Council, the European Economic and Social Committee and the Committee of the Regions. Green Infrastructure (GI) — Enhancing Europe's Natural Capital,” 2013.

[13] J. Maas, R. A. Verheij, P. P. Groenewegen, S. de Vries, and P. Spreeuwenberg, "Green space, urbanity and health: How strong is the relation?," J. Epidem. and Comm. Health, vol. 60, no. 7, pp. 587-592, 2006.

[14] P. Calaza and L. Ribeiro, "Assessing public health benefits through green infrastructure strategies in medium-sized cities in Spain. Case Study: La Coruña," presented at The Fábos Conference on Landscape and Greenway Planning. Pathways to sustainability, Amherst, USA, 2013.

[15] V. Tarzia (ECI), European Common Indicators: Towards a Local Sustainability Profile. Milano: Ambiente Italia Research Institute, 2003.

[16] ANGST, Natural England. "Accessible natural greenspace standard: Nature nearby," 2010. [Online]. Available: http://www.naturalengland.com.

[17] G.C. Wendel-Vos, A.J. Schuit, R. de Niet, H.C. Boshuizen, W.H. Saris, and D. Kromhout, "Factors of the physical environment associated with walking and bicycling." Med. Sci. Sports. Exerc. Apr, vol. 36, no. 4, pp. 725-30, 2004.

[18] F. Muñoz, Urbanalización: paisajes comunes, lugares globales. Barcelona: Gustavo Gili, 2008.

[19] K. Tzoulas, K. Korpela, S.Ven, V. Yli-Pelkonen, A. Ka'ZZmierczak, J. Niemela, and P. James, "Promoting ecosystem and human health in urban areas using green infrastructure: A literature review," Landscape and Urban Planning, vol. 81, pp. 167-178, 2007.

[20] J. Helms (Ed.), Dictionary of Forestry. Bethesda, MD: Society of American Foresters, 1998.

[21] C.C. Konijnendijk, T.B. Randrup, and K. Nilsson. "Urban forestry research in Europe: An overview," Journal of Arboriculture, vol. 26, no. 3, pp. 152-161, 2000. 
[22] C. Mattheck and H. Breloer, The Body Language of Trees - A Handbook for Failure Analysis. London: HMSO, 1994.

[23] C. Mattheck, H. Gerhardt, and H. Breloer, "VTA: Visual tree defect assessment based on computer simulation of adaptive growth," presented at Experimental Mechanics. Technology Transfer between High Tech Engineering and Biomechanics International Conference, pp. 109-120, Limerick, Ireland, 4-5 September 1992.

[24] W.A. Kenny, P. van Wassenaer, and A. Satel, "Sustainable urban forest management planning using criteria and indicators," presented at Urban Forest Innovations Inc. MillionTreesNYC, Green Infrastructure and Urban Ecology: A Research Symposium, March 5-6, 2010. [Online]. Available: http://escholarship.bc.edu/cate/vol3/iss1/16.

[25] P. Calaza Martínez and L. Rodriguez Quintanilla, "integration of hazard risk assessment in urban tree management. Case study: La Coruña. (Spain),” presented at 16th European Forum on Urban Forestry, Milano, Italy, 7 - 11 May, 2013.

[26] F. S. Santamour, "Trees for urban planting: diversity, uniformity and common sense," presented at 7Th conference Metropolitan Tree Improvement Alliance (METRIA) 7, pp. 57-65, 1990.

[27] J. C. Schwab, Planning the Urban Forest. Chicago, Illinois: American Planning Association, 2009.

[28] P.J.E. van Wassenaer, A.L. Satel, W.A. Kenney, and M. Ursic, "A framework for strategic urban forest management planning and monitoring," presented at Trees, people and the built environment Proceedings of the Urban Trees Research Conference, 13-14 April, Birmingham, 2011.

[29] N. Matheny and J. Clark, A Photographic Guide to the Evaluation of Hazard Trees in Urban Areas. Savoy, IL: International Society of Arboriculture, 1994.

[30] J. Albers, T. Eiber, and E. Hayes, "How to recognize hazardous defects in trees." 1996. [Online]. Available: http://www.na.fs.fed.us/spfo/pubs/howtos/ht_haz/ht_haz.htm.

[31] W. Wagener, Judging Hazard from Native Trees in California Recreational Areas: A Guide for Professional Foresters. U.S. For. Serv. Res. Pap. Pacif. Sthwest. For. Range Exp. Sta. No. PSW-P1, 1963.

[32] P. Calaza Martínez and M. I. Iglesias Díaz, Evaluación de riesgo de arbolado peligroso: principios, indicadores y métodos. Valencia: Asociación Española de Arboricultura y Universidad de Santiago de Compostela, 2012.

[33] R. W. Harris, J. R. Clark, and N. P. Matheny, Arboriculture. Integrated Management of Landscapes Trees, Shrubs and Vines. 4 ed. New Jersey, U.S.: Prentice Hall, 2004.

[34] M. Baietto, L. Pozzi, A.D. Wilson, and G. Bassi, "detection of roots rots of shade species by the use of a portable MOS electronic nose," presented at $16^{\text {th }}$ European Forum of Urban Forestry, Milano, Italy, 2013.

[35] H. Repton, Observations on the Theory and Practice of Landscape Gardening. London: 1803. 
